\title{
FRAUD: AN SMME PERSPECTIVE
}

\author{
Suzette Viviers* and Danie Venter \\ Nelson Mandela Metropolitan University \\ Department of Business Management / Department of Statistics \\ Nelson Mandela Metropolitan University \\ suzette.viviers@nmmu.ac.za \\ Tel: 0415044062 \\ Fax: 0415832644
}

\begin{abstract}
Given the important socio-economic role performed by Small, Medium and Micro Enterprises (SMMEs) and the negative consequences of fraud on their businesses, the objective of this study was to investigate the perceptions and management of fraud by SMME owners/managers. Respondents were of the opinion that fraud is a serious and increasing problem in corporate South Africa and viewed ethics policy implementation and internal controls as important measures of fraud detection and prevention. Only 10 per cent of respondents, however, made provision in their budgets for combating fraud. It is recommended that SMME owners/managers gain more knowledge on inexpensive yet effective fraud detection and prevention measures.
\end{abstract}

Key words and phrases: Small, Medium and Micro Enterprises (SMMEs), causes of fraud, fraud detection, fraud prevention, internal controls, ethics programmes.

\section{Introduction}

The socio-economic function performed by Small, Medium and Micro Enterprises (SMMEs) is widely recognised, both internationally and in South Africa. A report by the Department of Trade and Industry indicates that this sector accounts for almost 75 percent of all employment in South Africa and contributes approximately 28 percent to Gross Domestic Product (Wadula, 2005:1). Despite their important contribution to the socio-economic development of South Africa, many SMMEs are exposed to the high cost of the fraud wave currently engulfing corporate South Africa.

It is conservatively estimated that fraud is costing South Africa R80 billion a year or 6.6 percent of GDP; with an average of 6 percent of organisations' turnover being lost due to fraud (Interactive workshop on fraud, 2005:1). The true cost of fraud, however, goes beyond the financial loss and has implications for the firm's reputation, morale and management time, as well as trust within the business (Savage, 2003:6).

Pollick (2006) broadly defines fraud as “...deception made for personal gain; deliberate misinterpretation, which causes another person to suffer damages, usually in the form of property and/or services gained unjustly". Davies (2000:1) likewise defines fraud as "... all those activities involving dishonesty and deception that can drain value from a business, directly or indirectly, whether or not there is a personal benefit to the fraudster". From the above definitions it is clear that fraud includes a wide range of activities, from mismanagement, theft and manipulation to white-collar crime, all of which involve some element of deception. For the purposes of this study, fraud was defined as deliberate deceit, planned and executed, with the intent to deprive another of their property or rights. 
SMMEs are particularly vulnerable to fraud as they do not have adequate strategies or budgets to combat it (Le Roux, 2005:1; Mayles, 2005:1). Unfortunately, the prevention of fraud is often viewed by SMME owners/managers as a costly and unnecessary exercise, which in turn leads to many SMME owners/managers growing secure in the belief that their businesses are immune to fraud (Morris, 2006:2).

\section{Literature review}

In the following section a brief overview is presented of the causes of fraud, stakeholder involvement in fraudulent activities and fraud detection and prevention measures.

\section{Causes of fraud}

According to Wells (2005), the three main causes of fraud are pressure, opportunity and rationalisation. Wells (2005) argues that if all three of these elements are present it is highly probable that an individual will commit fraud. Examples of pressures that can lead to fraudulent activities are indicated in Table 1.

Table 1: Pressures that can lead to fraudulent activities

\begin{tabular}{|l|l|l|}
\hline \multicolumn{1}{|c|}{ Financial pressures } & Work-related pressures & \multicolumn{1}{c|}{ Other pressures } \\
\hline - Greed & - Unfair remuneration: real or & - Ambition or need for power \\
- High levels of personal debt & perceived & or control \\
- Living beyond one's means & - Lack of promotion & - Low self-esteem \\
- Inadequate income & - No recognition of & - Family or peer pressure \\
- Bad investments & performance & - Emotional instability \\
- The need to support addictive & - Unethical practices by & - No fear of retribution or \\
behaviour, e.g. drug and & management itself & enjoying the challenge of \\
alcohol abuse or gambling & - Lack of job stability & "beating the system" \\
& - Over-aggressive bonus plans & - Disintegration of social \\
& & values \\
\hline
\end{tabular}

Source: Adapted from Romney and Steinbart (2003:280) and Minnaar-van Veijeren (2005:1)

It can be argued that financial and work-related pressures are the most prevalent in the South African context. Research by De Vynck (2005:1) indicates that the typical fraudster in South Africa is likely to be a male, between the ages of 31 and 45, who commits fraud due to the increasing costs of raising a family, the added financial pressure of buying a home and the escalating cost of education. According to Van Wyk (2005:2), financial pressure is a prominent cause of fraud in countries with a high unemployment rate, such as South Africa.

It has been said that "love is blind but greed is deaf..." (Basson, 2000:40). Kennaugh (2000:23) agrees and states that greed plays a crucial role in an individual's motivation to commit fraud.

Opportunity refers to the condition or situation that allows a person to commit and conceal a fraudulent act (Camerer, 2006:1). According to Rossouw and Van Vuuren (2004:60), three actions are required to constitute an opportunity for fraud, namely:

- The person must be in a position of power or must have access to people in positions of trust in an organisation. 
- The person must understand the control system of the organisation as this gives him or her the ability to beat it.

- The person must have access to the assets of the business.

Opportunities often result from the lack of adequate internal controls that typifies many SMMEs (Romney \& Steinbart, 2003:281).

Fraudsters have many excuses or rationalisations which are used to justify their behaviour. The two most common forms of rationalisation are "I am just borrowing", or "everyone else is doing it". Other explanations given are that they are "not hurting a real person" or that they will do it "just this once" (Romney \& Steinbart, 2003:281).

Le Roux (2005:1) states that SMMEs are plagued by fraud on three fronts: misconduct, general ledger 'mess' and payment from debtors. In terms of misconduct, it was found that fraud is normally committed by the owner or management of the SMME, as these individuals have unlimited access to company coffers.

General ledger 'mess' refers to cases where the bookkeeper manipulates figures to reflect a skewed financial position of the SMME. In most cases the perpetrator is better off financially as a result of the deed. This problem is rife in SMMEs, as many entrepreneurs do not have accounting expertise, which compels them to outsource this function to bookkeepers, who in turn prey on their lack of understanding of hidden fraudulent transactions.

Employees responsible for the payment from debtors normally carry out the third type of typical SMME fraud. This form of fraud entails the creation of a shell company where fictitious debtors are created by the employee and money is siphoned off from the payment of debtors.

\section{Stakeholder involvement in fraudulent activities}

Internal stakeholders, such as employees and managers, are frequently the main culprits in fraudulent activities (Kennaugh, 2000:23; Motale, 2006:3; Payne, 2000:5). Makin and Botes (2005:1), for example, state that more than 50 percent of fraudsters in South Africa are in management positions. In contrast, the 2005 KPMG Survey indicates that only 19 percent of uncovered fraud in large businesses involved managers. This apparent discrepancy is in line with Hazelhurst's (1999:55) comment that fraud committed by management often goes undetected, as managers frequently have the ability to override internal controls over financial and other records.

SMME customers are likely to commit fraud if opportunities present themselves. As most SMMEs accept credit cards, they become susceptible to the risk of credit card fraud. Suppliers too may take advantage of SMMEs because of a lack of appropriate control. This may result in fewer items being delivered than stated on the delivery note or, perhaps worse, the wrong type of goods being delivered (Indications of fraud, 2006:4). Technological advances further present an increasing range of opportunities for external stakeholders to defraud SMMEs. For example, software can be downloaded from the Internet which enables fraudsters to steal or copy data, alter programmes and cause systems to crash (Indications of fraud, 2006:2). 


\section{Fraud detection measures}

Measures to detect fraudulent activities often include access controls, CCTV, security equipment, internal and external audits and whistle-blowing mechanisms. Unfortunately many SMME owners/managers view such measures as a costly and unnecessary expenditure. As such, many do not employ any measures to detect fraud in their businesses (Difficulty in quantifying, 2006:1; Le Roux, 2005:1).

According to the Ernst and Young fraud and risk prevention business guide (2005:20), certain "red flags" point to fraud being perpetuated in a business. Some of the most pertinent of these include:

- A high turnover rate of key accounting and financial personnel;

- Low morale;

- An employee whose lifestyle is at variance with his or her known sources of income;

- Changes in lifestyle or habits by key members of staff;

- Excessive hours worked by key staff; and

- A lack of delegation of apparently mundane tasks by key staff.

\section{Fraud prevention measures}

Besides having fraud detection measures in place, SMME owners/managers should also critically consider the ethical example which they set. According to Payne (2000:5), attitudes and behaviour of employees toward economic crimes are more strongly influenced by the ethical tone and commitment at the top than by policies and procedures which are laid down to combat crime. Unfortunately, top-level managers are often powered by greed and are in a position to cover up their actions (Kennaugh, 2000:23).

The development of a fraud policy and fraud response plan as part of a comprehensive ethics programme is also essential to effectively combat and manage the incidence of fraud in SMMEs (Fighting fraud, 2006:7; Moulton, 2005:1).

\section{Problem statement and research aims}

Given the adverse consequences fraud holds for SMMEs, their stakeholders and the South African economy, it is important to gain a better understanding of the causes thereof as well as preventive measures which SMME owners/managers can implement to detect and manage it.

The primary objective of this study was to investigate the perceptions and management of fraud by owners/managers of South African SMMEs. To achieve the primary research objective, the following secondary objectives were formulated:

- To conduct a literature review of various elements of fraud in corporate South Africa;

- To modify and contextualise an existing KPMG fraud questionnaire to the SMME sector in South Africa;

- To conduct an empirical investigation of the perceptions and management of fraud by owners/managers of South African SMMEs; and 
- To provide pertinent recommendations based on the empirical results.

By giving effect to these research objectives, it is hoped that a valuable contribution will be made to the body of knowledge regarding fraud in the local SMME sector. In the following section, the research design and methodology of this study will be discussed.

\section{Research Methodology}

A positivistic research paradigm was adopted for this study. This approach consists of several beliefs about how a researcher can make sense to others and is based on the assumption that all researchers are fallible. As such, it is posited that human behavioural studies should be conducted in the same manner as studies in the natural sciences (Blumberg, Cooper \& Schindler, 2005:18-19). The adoption of a positivistic research paradigm called for the collection and analysis of quantitative data, which were analysed using descriptive and inferential statistics. Care was taken to ensure the validity, reliability and general applicability of the findings.

\section{Population and sample}

The target population comprised an estimated all SMMEs operating in the Nelson Mandela Bay region (Port Elizabeth, Uitenhage and Despatch) irrespective of industry. Although no statistics are available on the actual number of SMMEs operating in the Nelson Mandela Bay region, Ms Mattheus, Editor of the Nelson Mandela Bay 2007 Business Guide, estimated on 1 April 2007 that there might be as many as 18000 SMMEs operating in the area (Mattheus, personal communication, 2007).

To address the problem of low response rates associated with mail and telephonic interviews, it was decided to personally deliver the questionnaires to the owners or general managers of a convenience sample of 475 SMMEs in the region. Time and financial constraints made it impossible to select a bigger sample.

\section{Measuring instrument}

The 2005 KPMG Africa Fraud and Misconduct Survey questionnaire was modified and contextualised for application to the local SMME sector.

In section A of the questionnaire, the focus was on the demographic characteristics of the respondent (age, gender, number of years of business experience, function, position in the business and level of education) and his or her business (size of business in accordance with the National Small Business Act No. 102 of 1996 and the branch of industry).

Section B of the questionnaire dealt with the perceptions and management of fraud by local SMME owners/managers. The questionnaire consisted mainly of fixed-response questions, with provision for some open-ended responses. In contrast to the 2005 KPMG Africa Fraud and Misconduct Survey, all items were arranged on a five-point Likert scale, some ranging from 'Not important at all' to 'Very important', whereas others gauged perceptions ranging from 'Strongly disagree' to 'Strongly agree'. A 
fixed response methodology was used to simplify the calculation of reliable summated scores.

\section{Procedure}

During the months of July and August 2006 questionnaires were distributed to the sample of 475 SMMEs in the Nelson Mandela Bay region. Field workers provided a brief overview of the research objectives, instructed respondents regarding the completion of the questionnaire and collected the questionnaires at the respondents' earliest convenience. Of the 475 questionnaires distributed, only 300 completed questionnaires were suitable for statistical analysis.

Item analyses were conducted and descriptive and inferential statistics were calculated, using the Microsoft Excel and Statistica packages.

\section{Results}

In the following section the most pertinent empirical findings are highlighted.

\section{Sample distribution}

The majority of respondents ( 72 percent) in this study were male. This finding should be viewed in the light of the fact that there are almost twice as many male entrepreneurs in South Africa as female entrepreneurs (Driver, Wood, Segal \& Herrington, 2001:22). More than a quarter of the respondents (27 percent) were between the ages of 30 and 49. In terms of years of experience in business, almost half of the respondents (47 percent), had over 15 years' experience, whereas 60 percent had more than ten years' experience. This suggests that the majority of the respondents were knowledgeable about the South African business environment. With regard to the level of education, most respondents had either a grade 12 certificate or equivalent or a National Certificate or Diploma (67 percent combined). Of the SMMEs surveyed, 31 percent were considered to be micro enterprises, 58 percent small businesses and only 11 percent of the businesses met the criteria of a mediumsized business. With regard to the industry in which the respondents operated, the majority were in retailing/wholesaling (36 percent) and business or personal services sector (35 percent).

\section{Perceptions of respondents regarding the prevalence of fraud in South Africa}

Compared with businesses in the 2005 KPMG Survey, a larger proportion of SMME owners/managers perceived fraud to be a serious problem in South Africa (81 percent versus 64 percent of respondents in the KPMG survey). It should be noted that respondents in the 2005 KPMG Survey were mainly employed in large businesses, i.e. businesses employing 251 or more employees. In terms of whether respondents perceived fraud as likely to increase in corporate South Africa in future, similar responses were observed in the two surveys (68 percent and 67 percent of respondents respectively). 


\section{Perceptions of respondents regarding the main causes of fraud}

Responses of SMME owners/managers and large businesses in respect of the main causes of fraud in South Africa are shown in Table 2.

Table 2: Causes of fraud in South Africa

\begin{tabular}{|l|c|c|}
\hline Cause & $\begin{array}{l}\text { Ranking by } \\
\text { SMMEs } \\
\text { In this survey }\end{array}$ & $\begin{array}{l}\text { Ranking by large businesses } \\
\text { in the 2005 KPMG Survey }\end{array}$ \\
\hline The weakening of society's values & $1(81 \%)$ & $3(58 \%)$ \\
\hline Sophistication of criminals & $2(72 \%)$ & $1(68 \%)$ \\
\hline Financial pressure & $3(63 \%)$ & $2(67 \%)$ \\
\hline
\end{tabular}

It is interesting to note that 81 percent of SMME owners/managers viewed the weakening of society's values as the most important cause of fraud, whereas only 58 percent of respondents in large businesses viewed it as important. The fact that SMME owners/managers ranked the weakening of society's values as the number one cause is in sharp contrast to literature on this topic. As indicated earlier, financial pressure is generally seen as the most important cause of fraud globally and in South Africa (De Vynck, 2005:1; Minnaar van Veijeren, 2005:2; Romney \& Steinbart, 2003:280).

This finding may be attributed to the fact that SMME owners/managers are in closer proximity to the general public and might therefore be more aware of unethical activities that are occurring in society. In contrast, the respondents of the 2005 KPMG Survey, mainly CEOs, CFOs and the Heads of Internal Auditing, are a bit further removed from the "average citizen" and hence less sensitive to changes in society's values.

Greater Internet usage, e-commerce and e-banking were also seen by respondents in both surveys as important contributors to fraud.

\section{Perceptions of respondents regarding stakeholder involvement in fraudulent activities}

In line with the literature (Indications of fraud, 2006:2; Kennaugh, 2000:23; Motale, 2006:3) and the 2005 KPMG Survey, SMME owners/managers in this study perceived internal stakeholders i.e. employees and managers, as more likely to engage in fraudulent activities than external stakeholders.

The factors Internal stakeholders and External stakeholders had mean scores of 3.55 and 3.04 respectively and standard deviations of 0.87 and 0.84 respectively. Cronbach's Alpha Coefficients for the two factors were equal to 0.50 and 0.62 . According to Nunally (1978:226), coefficients of 0.50 and better are sufficient indicators of reliability in the early stages of basic research. 


\section{Losses suffered as a result of fraud}

The most prevalent losses reported by SMMEs in this study were: the theft of physical assets such as inventory and equipment (37 percent of respondents reporting significant losses), the theft of money ( 22 percent), the theft of intellectual property (18 percent), cheque fraud (15 percent) and bid rigging (10 percent).

This ranking differs from that of the 2005 KPMG Survey, where twice as many respondents in large businesses (48 percent) reported significant losses associated with the theft of money. Although ranked second, a similar proportion of large businesses (40 percent) experienced the theft of physical assets as a significant loss. The fact that SMMEs suffer more losses from the theft of physical assets might be attributed to the lack of security measures, such as CCTV, in these businesses compared to larger firms. SMME owners/managers might also have more control over the cash of the business (signing and receiving cheques).

A few SMME respondents also remarked that employees' laziness (i.e. the theft of time) is also a type of loss frequently suffered by SMMEs.

\section{Fraud detection measures employed by SMME owners/managers}

As shown in Table 3, factor analysis of "red flags" yielded three factors that can be labelled: Lifestyle changes, Financial pressure and Long working hours. All factor loadings were in excess of 0.59 and Cronbach's Alpha Coefficients in excess of 0.70, thus confirming the reliability of the derived summated scores.

Table 3: Factors that may indicate that fraud is being perpetrated in an SMME

\begin{tabular}{|c|c|c|c|c|}
\hline Factor & $\begin{array}{l}\text { Cronbach's } \\
\text { Alpha } \\
\text { Coefficients }\end{array}$ & "Red flags" & $\begin{array}{l}\text { Mean } \\
\text { scores }\end{array}$ & $\begin{array}{l}\text { Standard } \\
\text { deviation }\end{array}$ \\
\hline $\begin{array}{l}\text { Lifestyle } \\
\text { changes }\end{array}$ & 0.71 & $\begin{array}{ll}- & \text { Always able and quick to supply } \\
\text { answers } \\
-\quad \text { Ongoing transactions with related } \\
\text { parties } \\
-\quad \text { Extravagant purchases or lifestyle } \\
-\quad \text { Vices e.g. abuse of drugs, alcohol } \\
\text { or gambling }\end{array}$ & 3.44 & 0.91 \\
\hline $\begin{array}{l}\text { Financial } \\
\text { pressure }\end{array}$ & 0.74 & $\begin{array}{ll}- & \text { Unnecessarily complicated } \\
& \text { transactions } \\
- & \text { Internal pressure e.g. management } \\
& \text { pressure to meet budgets } \\
- & \text { Increased stress } \\
- & \text { Real or imagined grievances } \\
& \text { against the company } \\
- & \text { Personal financial pressure } \\
\end{array}$ & 3.23 & 0.83 \\
\hline $\begin{array}{l}\text { Long } \\
\text { working } \\
\text { hours }\end{array}$ & 0.78 & $\begin{array}{ll}- & \text { Refusal to delegate tasks } \\
- & \text { Short or no vacation } \\
- & \text { Unexplained or long working hours }\end{array}$ & 3.10 & 1.04 \\
\hline
\end{tabular}

From the mean scores shown in Table 3 it is evident that Lifestyle changes constitute the most prominent indicator of fraud being perpetuated, followed by Financial 
pressure and Long working hours. A similar ranking of indicators was observed in the 2005 KPGM Survey. These findings also correspond with the literature outlined earlier (Ernst and Young fraud and risk prevention business guide, 2005:20; Powell, 2004:3). The factor of long working hours presents a common problem experienced by SMME owners and not only creates an opportunity for them to commit fraud, but also gives them a basis upon which to rationalise their behaviour (Van Eeden, Viviers \& Venter, 2003:13).

Although research by Auriacombe (2005:88) shows that whistle-blowing encourages businesses to be more receptive to information on fraudulent activities, only 23 percent of SMMEs had whistle-blowing mechanisms in place for their employees, only 16 percent for their suppliers and a mere 3 percent for their customers. In contrast. 59 percent of large businesses in the 2005 KPMG Survey reported having whistle-blowing hotlines available to their employees, 34 percent for suppliers and 53 percent for customers.

Perhaps it is easier to remain anonymous within a large business, prompting more large businesses to offer hotlines to their stakeholders, particularly employees. On the other hand, SMMEs are often typified by close relationships between the employer and employees, allowing for greater trust and transparency. The lack of knowledge regarding whistle-blowing hotlines among SMME owners/managers might also contribute to their not utilising this fraud detection measure.

\section{Actions taken upon the discovery of fraud}

As indicated in Table 4, the most prominent actions taken by SMMEs upon the discovery of fraud are conducting internal investigations and disciplinary hearings. These findings are similar to those of the 2005 KPMG Survey with the exception of "disciplining offenders", which SMME owners/managers are much more likely to do. In this regard Thompson and Strickland (2003:445) caution that the main purpose of enforcement should always be to "...encourage compliance rather than administer punishment".

Table 4: Actions taken upon the discovery of fraud

\begin{tabular}{|l|c|c|c|c|}
\hline \multicolumn{1}{|c|}{ Item } & $\begin{array}{c}\text { Mean } \\
\text { scores }\end{array}$ & $\begin{array}{c}\text { Standard } \\
\text { deviations }\end{array}$ & $\begin{array}{c}\text { SMMEs } \\
\text { 'always' do } \\
\text { it }\end{array}$ & $\begin{array}{c}\text { Large businesses } \\
\text { 'always' do it }\end{array}$ \\
\hline Conduct an internal investigation & 4.25 & 1.05 & $56 \%$ & $53 \%$ \\
\hline $\begin{array}{l}\text { Set an example e.g. disciplining an } \\
\text { offender and communicating it to } \\
\text { others }\end{array}$ & 4.18 & 1.06 & $52 \%$ & $20 \%$ \\
\hline Disciplinary hearing & 4.12 & 1.18 & $53 \%$ & $55 \%$ \\
\hline Immediate dismissal & 4.05 & 1.14 & $48 \%$ & $55 \%$ \\
\hline Report to the police & 3.54 & 1.33 & $34 \%$ & $43 \%$ \\
\hline $\begin{array}{l}\text { Take civil action for recovering } \\
\text { losses }\end{array}$ & 3.17 & 1.35 & $21 \%$ & $21 \%$ \\
\hline File an insurance claim & 2.88 & 1.39 & $16 \%$ & $23 \%$ \\
\hline Negotiated settlement & 2.73 & 1.32 & $12 \%$ & $12 \%$ \\
\hline Keep it quiet & 1.79 & 1.17 & $5 \%$ & \\
\hline
\end{tabular}


Only 34 percent of SMME owners/managers reported incidents of fraud to the police. This is lower than the percentage of large businesses in the 2005 KPMG Survey (43 percent), but supports Moulton's (2005:1) argument that SMMEs often fail to report fraud as they fear it would tarnish their reputation. Fifty-seven percent of respondents failed to report incidents of fraud to the police as they had no confidence in the justice system in South Africa.

\section{Fraud prevention measures implemented by SMME owners/managers}

Two factors dealing with fraud prevention measures were identified: Ethics policy implementation and Internal control measures. The relevant statistics pertaining to these factors are illustrated in Table 5. All Cronbach's Alpha Coefficients were in excess of 0.6 and all factor loadings were in excess of 0.63 .

Table 5: Ethics policy implementation and internal control measures

\begin{tabular}{|c|c|c|c|c|}
\hline Factor & $\begin{array}{l}\text { Cronbach's } \\
\text { Alpha } \\
\text { Coefficients }\end{array}$ & Items & $\begin{array}{l}\text { Mean } \\
\text { scores }\end{array}$ & $\begin{array}{l}\text { Standard } \\
\text { deviations }\end{array}$ \\
\hline $\begin{array}{l}\text { Ethics policy } \\
\text { implementation }\end{array}$ & 0.80 & $\begin{array}{ll}- & \text { Establishing a } \\
\text { corporate code of } \\
\text { conduct } \\
-\quad \text { Establishing a fraud } \\
\text { policy } \\
-\quad \text { Implementing a } \\
\text { comprehensive } \\
\text { ethics programme } \\
- \text { Offering training } \\
\text { programmes on } \\
\text { fraud detection and } \\
\text { prevention }\end{array}$ & 3.97 & 0.83 \\
\hline $\begin{array}{l}\text { Internal control } \\
\text { measures }\end{array}$ & 0.67 & 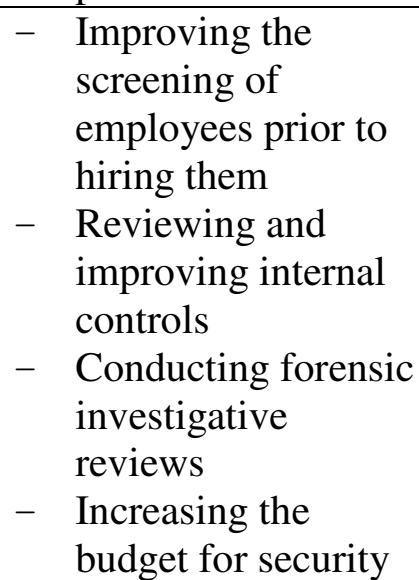 & 3.88 & 0.73 \\
\hline
\end{tabular}

The first factor essentially deals with the institutionalisation of ethics by developing and implementing a comprehensive ethics programme (Rossouw \& Van Vuuren, 2004:80). It is encouraging to note that almost half of the respondents (46 percent) have a fraud policy in place, despite the fact that only ten percent have funds available for the implementation thereof. Although a similar percentage of large businesses in 
the 2005 KPMG Survey (45 percent) indicated having a fraud policy, many more (33 percent) made provision for fraud investigations in their budgets.

Compared with large companies in the 2005 KPMG Survey, in which 42 percent of the respondents indicated that internal control measures needed to be improved within their organisations, 75 percent of SMME owners/managers saw a need for improved internal control measures. These statistics show that SMME owners/managers, although financially constrained, are aware of the need to improve internal controls as a measure for combating fraud.

\section{Respondents' views on the importance of managing fraud}

Just more than half (55 percent) of SMME owners/managers indicated that the management of fraud is good business practice. This is significantly lower than the 71 percent of respondents in the 2005 KPMG Survey. This might be attributed to lower levels of knowledge among SMME owners/managers as to what fraud exactly entails.

\section{Discussion}

Table 6 provides the main differences and similarities between the responses of SMME owners/managers in this survey and those of respondents from large businesses in the 2005 KPMG Survey.

Table 6: Salient empirical findings

\begin{tabular}{|c|c|}
\hline Topic & Comment \\
\hline $\begin{array}{l}\text { The prevalence of } \\
\text { fraud in South } \\
\text { Africa }\end{array}$ & $\begin{array}{l}\text { Compared with large South African businesses, more SMME owners/managers } \\
\text { perceived fraud to be a serious problem ( } 81 \text { percent versus } 64 \text { percent). In both } \\
\text { surveys more than two-thirds of respondents expected fraud to increase in future. }\end{array}$ \\
\hline d & $\begin{array}{l}81 \text { percent of SMME owners/managers viewed the weakening of society's values } \\
\text { as the most important cause of fraud in South Africa, whereas only } 58 \text { percent of } \\
\text { respondents in larger businesses viewed it as important. Similar views were } \\
\text { expressed regarding the other causes of fraud, such as financial pressure, more } \\
\text { sophisticated criminals and the increased use of Internet based technologies. }\end{array}$ \\
\hline $\begin{array}{l}\text { Stakeholder } \\
\text { involvement in } \\
\text { fraudulent } \\
\text { activities }\end{array}$ & $\begin{array}{l}\text { Similar findings were reported in the two surveys in that internal stakeholders, } \\
\text { i.e. employees and managers, were seen as the main perpetrators of fraud. }\end{array}$ \\
\hline $\begin{array}{l}\text { Losses suffered as } \\
\text { a result of fraud }\end{array}$ & $\begin{array}{l}\text { Respondents in both surveys mainly suffered losses from the theft of physical } \\
\text { assets and money. }\end{array}$ \\
\hline $\begin{array}{l}\text { Fraud detection } \\
\text { measures }\end{array}$ & $\begin{array}{l}\text { In both surveys red flags pertaining to lifestyle changes were seen as the most } \\
\text { important indicators of fraud, followed by items relating to financial pressure and } \\
\text { long working hours. In contrast to large businesses, very few SMMEs had } \\
\text { whistle-blowing mechanisms in place. }\end{array}$ \\
\hline $\begin{array}{l}\text { Actions taken } \\
\text { upon the } \\
\text { discovery of fraud }\end{array}$ & $\begin{array}{l}\text { In both surveys, internal investigations were the primary action undertaken upon } \\
\text { the discovery of fraud. Compared with large businesses, SMME } \\
\text { owners/managers were more inclined to discipline offenders and less likely to } \\
\text { report incidents of fraud to the police, mainly due to a lack of confidence in the } \\
\text { judicial system and due to a fear of negative publicity. }\end{array}$ \\
\hline $\begin{array}{l}\text { Fraud prevention } \\
\text { measures }\end{array}$ & $\begin{array}{l}\text { As in the case of large businesses, SMME owners/managers viewed ethics policy } \\
\text { implementation and internal control measures as important fraud prevention } \\
\text { measures. Only } 10 \text { percent, however, have budgets available in this regard. }\end{array}$ \\
\hline $\begin{array}{l}\text { Views on the } \\
\text { importance of } \\
\text { managing frat }\end{array}$ & $\begin{array}{l}\text { Only } 55 \text { percent of SMME owners/managers, compared with } 71 \text { percent of large } \\
\text { business respondents, were of the opinion that the management of fraud } \\
\text { constitutes good business practice. }\end{array}$ \\
\hline
\end{tabular}




\section{Limitations of the study}

It is suggested that the relatively small sample size of 300 respondents be extended by repeating the study among SMMEs in other provinces in South Africa.

\section{Implications for management}

From Table 6 it is clear that several similarities exist between the perceptions and management of fraud among respondents in SMMEs and large businesses. The most striking differences were observed in terms of fraud budgets and knowledge regarding fraud prevention and control measures (particularly whistle-blowing mechanisms).

Based on the empirical evidence, a number of key recommendations can be made. It is firstly suggested that SMME owners/managers gain more knowledge on fraud detection and prevention measures. Such measures need not be complex or expensive and could involve simple actions such as:

- Controlling incoming mail by limiting access to it;

- Directly collecting bank statements from the bank and reviewing the contents thereof before reconciliation, as this will allow for the detection of any unusual transactions and immediate rectification;

- Regularly reviewing the approved list of vendors, as this will curb the creation and falsification of unknown vendors.

Other forms of prevention could include establishing and monitoring budgets, establishing reasonable performance targets for employees, requiring uninterrupted vacations for all employees and establishing of a rotation schedule of employees' responsibilities. The latter provides a strong disincentive to committing fraud, although it might prove difficult in SMMEs as most are characterised by a strong division of labour. SMME owners/managers also need to clearly communicate their fraud policy as part of a comprehensive ethics programme to all new employees.

The development of a fraud policy and fraud response plan as part of a comprehensive ethics programme is also essential to effectively combat and manage the incidence of fraud. It is important that SMME owners/managers set the "ethical tone and commitment at the top", as employees' attitudes and behaviour towards fraud are more strongly influenced by management's actions than by the policies and procedures which they lay down to combat it (Payne, 2000:5).

It is further suggested that SMME owners/managers educate themselves on the legal aspects of fraud detection (e.g. protection of privacy) and the disciplining of offenders (e.g. correct dismissal procedures). In this regard, sector training and education authorities (SETAs) and higher education institutions can play an important role.

These recommendations are particularly apt in the light of the fact that SMME owners/managers view fraud as becoming more prevalent in corporate South Africa. Unless they safeguard their businesses properly, more SMMEs will fall prey to unethical conduct of employees, customers and suppliers. 


\section{Conclusion}

Despite the negative consequences of fraud in the local SMME sector, very few owners/managers have an adequate understanding of the causes or costs thereof. Just more than half of the respondents were of the opinion that the management of fraud constitutes good business practice, which is in sharp contrast to $71 \%$ of respondents in large businesses. This study found that only ten percent of SMME owners/managers made provision for fraud detection and prevention measures in their budgets. The empirical evidence suggests that SMME owners/managers educate themselves on the topic with particular emphasis on the legal issues relating to fraud detection (e.g. protection of privacy) and the disciplining of offenders (e.g. correct dismissal procedures). Unless SMMEs safeguard their businesses properly, more will fall prey to the rising levels of unethical conduct among employees, customers and suppliers.

\section{Acknowledgements}

The authors wish to thank the following institutions and persons for their contributions to this study:

- The National Research Foundation and the Nelson Mandela Metropolitan University for financial support;

- Ms Jodè May for her valuable contribution;

- Mr Thinus Rheeder of KPMG for providing the 2005 Africa Fraud and Misconduct Survey questionnaire for use in this study.

\section{References}

Auriacombe, C. J. 2005. What happens when one blows the whistle? Politeia, 24(1): 88-100.

Basson, D. 2000. The psychology of fraud. Finance Week, 6:40.

Blumberg, B., Cooper, D.R. \& Schindler, P.S. 2005. Business research methods. London: McGrawHill.

Camerer, L. 2006. Corruption in South Africa: results of an expert panel survey. (3p). [Online] Available from: http://www.iss.co.za/Pubs/Monographs/No65/ Chap4.html [Accessed: 2006-01-10].

Davies, D. 2000. Fraud Watch. $2^{\text {nd }}$ ed. Johannesburg: KPMG Bottom line Business Guides.

De Vynck, D. 2005. Fraud is a repeated business. Business Report, 22 February. (1p). [Online] Available from: http://www.busrep.co.za/index.php? fSectionId=5618\&Article=241936.html [Accessed: 2006-03-03].

Difficulty in quantifying fraud costs doesn't give companies a licence for complacency. 2006. (1p). [Online] Available from: http://www.ey.com/ GLOBAL/content.nsf/South_Africa/know_Fraud_ Quarter_One_2006_-_Quantify_fraud_costs.html [Accessed: 2006-01-08].

Driver, A., Wood, E., Segal, N. \& Herrington, M. 2001. Global Entrepreneurship Monitor. Cape Town: The Graduate School of Business, University of Cape Town.

Ernst \& Young Fraud and Risk Prevention Business Guide. 2005. Ernest \& Young: Johannesburg.

Fighting fraud - a guide for SMEs. 2006. (12p). [Online] Available from: http://www.fraudadvisory panel.org /newsite/PDFs/advice/Fighting\%20Fraud.pdf [Downloaded: 2006-01-10].

Hazelhurst, E. 1999. Vigilance can weed out corruption. Financial Mail, 155(5):55. 
Indications of fraud in SMEs. 2006. (10p). [Online] Available from: http://www.fraudadvisorypanel. org/newsite/PDFs/advice/Indication\%20ofFraud.pdf [Downloaded: 2006-09-28].

Interactive workshop on fraud. 2005. (1p). [Online] Available from: http://www.gsb. uct.ac.za/ newsletter/newsletterArticle.ASP?intArticleID=914.html [Accessed: 2006-05-03].

KPMG Africa Fraud and Misconduct Survey. 2005. (113p). [Online] Available from: http://www. kpmg.co.za/library/detail.asp?libid=269\&month=4\&year=2002.html [Accessed: 2006-03-03].

Kennaugh, B. 2000. The state of the nation. Accountancy SA, 1:21, 23.

Le Roux, J. 2005. It is vital for SMMEs to quantify fraud costs accurately to avoid complacency. [Online] Available from: http://www.quantify_fraud_costs.index.html (1p).pdf [Downloaded: 2006-05$03]$.

Makin, V. \& Botes, V.L. 2005. Empowerment SA. (1p). [Online] Available from: http://www.empsa.co.za/newsletter/July-2005.html [Accessed: 2006-09-28].

Mattheus, B. 2007. Verbal communication (telephonic discussion) with the author on 1 April. Port Elizabeth.

Mayles, T. D. 2005. A fraud prevention mini-clinic. (1p). [Online] Available from: http://www.barneswendling.com/pdf/mayles_fraud.pdf [Downloaded: 2006-07-07].

Minnaar-Van Veijeren, J.M. 2005. Is South Africa winning the fight against white-collar crime? (5p). [Online] Available from: http://www.i-value.co.za/article1.html [Accessed: 2006-01-05].

Morris, R. 2006. SMEs not geared up to prevent fraud. (2p). [Online] Available from: http://www.beelistings.co.za/news.htm?more=131.html [Accessed: 2006-01-07].

Motale, S. 2006. Criminal misconduct cost R120 million. The Citizen, 9 February: 3.

Moulton, G. 2005. Organisational culture important in beating company fraud. (1p). [Online] Available from: http://www.busrep.co.za/index.php?fSecitonId=971\& ArticleId=2419011.html [Accessed: 2006-03-03].

Nunally, J. 1978. Psychometric theory. $2^{\text {nd }}$ ed. New York: McGraw-Hill.

Payne, N. 2000. Shepherding the shepherds. Accountancy SA, January: 5.

Pollick, M. 2006. What is fraud? [Online] Available from: http://www.wisegeek. com/what-is fraud.html [Accessed: 2006-07-20].

Powell, S. 2004. Red flags for white-collar crime. The Star, 15 November: 3.

Romney, M.B. \& Steinbart, P.J. 2003. Accounting Information Systems. $9^{\text {th }}$ ed. New Jersey: Prentice Hall.

Rossouw, D. \& Van Vuuren, L. V. 2004. Business Ethics. $3^{\text {rd }}$ ed. Cape Town: Oxford University Press Southern Africa.

Savage, M. 2003. Food for Insomnia. Accountancy SA, May: 6-7.

South Africa. 1996. National Small Business Act, No. 102 of 1996. Government Gazette, 17612(1901). (14p). [Online] Available from: http://www.info. gov.za/ gazette/acts/1996/a102-96.pdf [Downloaded: 2006-01-07].

Thompson, A.A. \& Strickland, A.J. 2003. Strategic management: concepts and cases. $13^{\text {th }}$ ed. New York: McGraw-Hill. 
Van Eeden, S.M., Viviers, S. \& Venter, D.J.L. 2003. A comparative study of selected problems encountered by small businesses in the Nelson Mandela, Cape Town and Egoli metropoles. Management Dynamics, 12(3): 13-23.

Van Wyk, M. 2005. Fraudulent financial reporting, power and financial governance: corporate governance. Accounting SA, (1): 2-4.

Wadula, P. 2005. Why SA's small businesses stay that way. Sunday Times, 3 January, (1p). [Online] Available from: http://www.sundaytimes.co.za/zones/ sundaytimesnew/business/business 1104744870. aspx.html [Accessed: 2006-01-03].

Wells, J.T. 2005. Why employees commit fraud. [Online] Available from: http://www.aicpa.org/PUB/JOFA/feb2001/wells.html [Accessed: 2006-03-03]. 